$$
\text { “. . . all of Egypt's foreign policy }
$$
moves in the 1970 s can and should be understood as resulting from its economic position." 


\section{HUNGER FOR PEACE:}

\section{Egypt's Economic Reasons to Seek Peace with Israel}

DAVID F. BRADLEY, JR.

IN 1978, EGYPT'S ANWAR AL-SADAT LAUNCHED A HISTORIC PEACE INITIATIVE WITH ISRAEL, ULTIMATELY CULMINATING IN A PEACE AGREEMENT THAT, NEARLY 30 YEARS LATER, STILLSTANDS. THIS PAPER TRACES EGYPT'S ECONOMIC STATUS UNDER ANWAR AL-SADAT AND CONCLUDES THAT SADAT, RATHER THAN IUST BEING AN INNATELY PEACE-LOVING MAN, HAD REAL ECONOMIC INCENTIVES IN SEEKING PEACE WITH ISRAEL. EGYPT DIVERTED RESOURCES FROM ITS INFRASTRUCTURE AND ITS PEOPLE IN ORDER TO PAY FOR A HEAVILY ARMED BORDER WITH ISRAEL. HOSTILITIES TOWARD ISRAEL ALSO COST THE COUNTRY FOREIGN DIRECT INVESTMENT AND FOREIGN AID FROM THE WEST. SADAT'S DESIRE FOR PEACE WAS LITERALLY HUNGER BECAUSE HIS CITIZENS WERE STARVING. 


\section{INTRODUCTION}

On January I8, I977, the smell of tear gas and gunpowder permeated the Cairo air. The people of Egypt were rising in protest against Anwar Al-Sadat and his latest policy move reducing the subsidies on basic products such as cigarettes, sugar, flour, rice, oil, beer, and cooking fuel. Although the policy decision that sparked the so-called "Food Riots" did not affect many staples, such as bread and tea, and the change in prices was generally small for the poor, teeming masses of Cairo, even the resulting small increase had significant repercussions. By the time the military put down the riot on the evening of January I9, security forces had killed 79 and injured 800 . ii It was the largest popular uprising since the Nasser Revolution of 1952 . Sadat later reversed the subsidy cuts.

The January 1977 riots were an indication of the failure of Sadat's economic policies from the previous four years. In that time, Sadat attempted to loosen the reins the state held on the economy through a series of policy decisions collectively called infitah, or "opening." By opening the economy, Sadat hoped to encourage Western businesses to move to Egypt and to stimulate the economy. However, liberalization in the economy was only one of the steps necessary to encourage foreign investment and foreign aid. Two other critical steps involved distancing Egypt from the Soviet Union and making a stable peace with Israel. To this end, after the riots, Sadat began planning for a major, public peace initiative with Israel. In November, ten months after the January riots, these plans came to fruition when Anwar al-Sadat made his famous speech in front of the Israeli Knesset. This sequence of events was no coincidence.

Domestic economic factors played a significant role in Sadat's moves for peace, not just in November 1977, but throughout the ig7os. When Sadat inherited control of Egypt from his predecessor, Gamal Abdal Nasser, in I970, the economy was in shambles. Egyptian pride was at an alarming low, and relations with both superpowers, the Soviet Union and the United States, were strained. Egypt's sense of lost honor and of rocky relations with the two su- perpowers factored into economic stagnation and even backslide. While the I973 Yom Kippur War ended with an eventual military defeat for Egypt, it helped restore Egyptian pride. Such sentiments paved the way for public acceptance of a lasting peace with Israel in 1977, which helped reduce the budgetary strain of maintaining a heavily militarized border on Sinai. Moreover, peace with Israel helped build the confidence of private foreign investors. Sadat's private negotiations with the Americans following the I973 war and his public distancing from the Soviet Union helped Egypt to gain American financial and military backing. Improved relations with the Western powers, particularly the United States, led to an increase in badlyneeded foreign aid. In short, all of Egypt's foreign policy moves in the I970s can and should be understood as resulting from its economic position.

\section{EGYPT'S ECONOMIC WOES}

From Nasser's 1952 revolution until the Camp David Accords, Egypt's economy had been disarrayed. Infrastructure was poor, and the constant threat of war made it difficult to find funds to improve its condition. Crowding in the cities following the exodus from Sinai and the closure of the Suez Canal also resulted from wars and threats of war. Author Anthony McDermott blames the political infrastructure created by Nasser for the economic decline: "If one is searching for a crucial reason why since I952 the economy has not taken off, and why, in spite of all the planning, the gap between targets and fulfillments has been so large, the establishment of this [new] bureaucracy may well provide the answer." iii By way of comparison, 250,000 Egyptians were in the civil service when Nasser took over in I952 while over one million were in the civil service by the I970s. ${ }^{\text {iv }}$

The legacy of Nasser's policies is significant for understanding the economic development of Egypt under Sadat. Nasser based his new government in 1952 on six "Revolutionary Principles," which included land reform, greater social justice, and liberal democracy. ${ }^{\mathrm{V}}$ Nasser decided that the socioeconomic condition of the country 
needed improvement before he could obtain his primary goal: liberal democracy. Nasser encouraged industrialization, adult literacy, and public education, yet the results of Nasser's programs left much to be desired. The policy of subsidizing staple goods arose during the reign of Nasser. He encouraged industrialization but nationalized private businesses-a certain way to discourage investment in industry. Attendance in public secondary and university-level schools skyrocketed, but there were no jobs for the college graduates-except in the massive government bureaucracy.vi The confiscatory and redistributive tax system, too, did nothing to help encourage foreign funds.

Egypt's military actions also drained the economy. During the War of 1956, many Egyptians living in Sinai fled to the cities, causing crowding problems in urban areas such as Cairo and Alexandria. In I967, this problem became much more acute. Egypt's high birthrate caused a 400 percent population increase from I897 to I977 with only a I27 percent rise in cultivated land, which spelled disaster for food supplies and infrastructure. ${ }^{\text {vii }}$ Maintaining military forces on the Sinai border further drained the national treasury. The military buildup along the Sinai border, even after the ceasefire agreements, was significant. In I976, Egypt had a 500,000-man army, all of whom, of course, needed food and payment. viii Not only was the military on the Sinai border, but several thousand soldiers were in Yemen engaged in a civil war there. ix The funding of the army consumed nearly 50 percent of Egypt's total budget and caused continual debt problems, leaving little room for other budgetary considerations, such as subsidizing food prices, without going into debt. The indirect costs of military action, including the closure of the Suez Canal and the loss of money from the oil fields in Israeli-occupied Sinai, were damaging as well. The Western foreign aid the country received in the Ig Gos dried up because of Egypt's close relations to the Soviet Union.

As Sadat rose to power in I970, Egypt's economic outlook was bleak. Growing national foreign debt, poor balance of trade, no foreign investment, and huge military expendi- tures plagued the country. The new leader had to do something to improve the economy so he decided to embark on a program of liberalization, or infitah. This program depended on foreign governmental aid and foreign direct investment money, neither of which Egypt received in the early I970s. Despite the establishment of free trade zones in Egypt, Foreign Direct Investment (FDI) was rare. ${ }^{\text {ix }}$

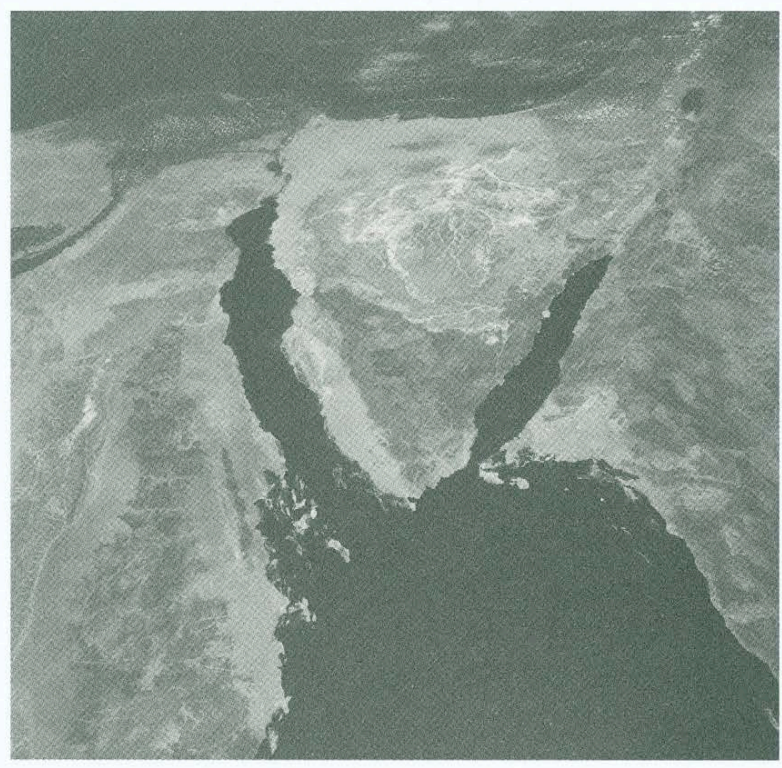

Following the I973 Yom Kippur War, this changedslightly. As mentioned above, the United States government and private American banks promised over \$I5O million in construction loans directly following the war to build an oil pipeline. More liberalization occurred, as Sadat granted foreign and domestic capitalist protections against nationalization of their businesses and reduced the taxes paid on business profits. Sadat attempted to form a mixed economy-one with a large public sector (through nationalized businesses and the ever-expanding national governmental bureaucracy) and heavy food subsidies, combined with attempts at private business ownership.

However, Sadat's efforts were ineffective, as he lacked a thorough understanding of economics. Instead, he left many of the economic details to his advisors-most of 
whom were bona-fide Marxists. ${ }^{x}$ Although Sadat talked often - and earnestly — of easing economic restraints and encouraging capitalism through his infitah program, it was not until I98I that Egypt ended the most anti-capitalist laws such as the capping of annual salaries and profits. During the I970s, central planning, through Soviet-style "five-year programs," framed economic development. The trappings of socialism remained, including high, confiscatory taxation, heavy central planning, and relative minimum wage (a system under which businesses had to pay employees a certain percentage of that business's profits), inhibiting local industrial capitalists. ${ }^{\mathrm{x} i}$

A perceived absence of peace in the region also accounted for the scarcity of FDI. Even after the Sinai ceasefire accords and the opening of the Suez Canal, the threat of war seemed high to many foreign businesses-too high, in

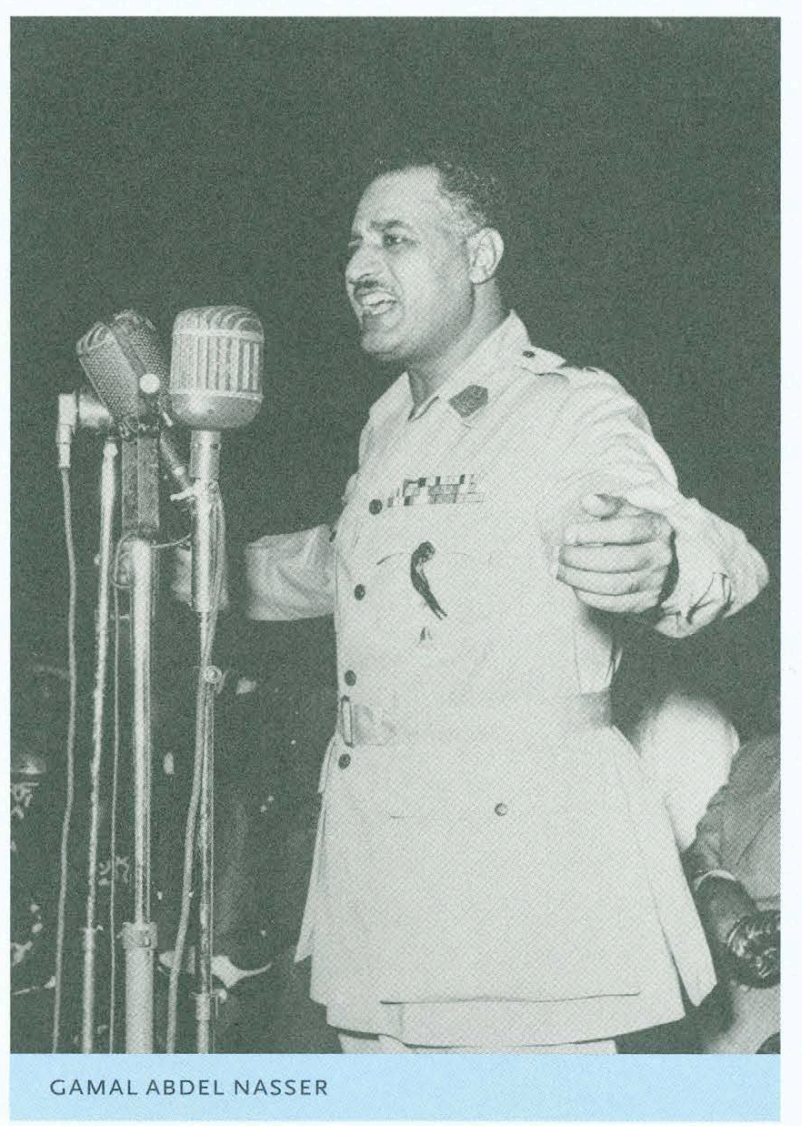

Israel would allow these companies to enter Egypt.

Despite Sadat's best intentions, infitah failed-as the 1978 Food Riots seemed evidence of that. The riots resulted from Sadat's reduction in the food subsidies, an act fitting with his other attempts at liberalization. It was an attempt to placate the IMF, which was demanding that Egypt balance its budget as part of its debt relief program. After seeing the uproar created by the subsidy decreases, Sadat knew he would not be able to reduce the subsidies and remain in power; thus, he sought another way of decreasing budgetary strains. There was one other path to take to balance the budget, and it required two actions: I) to increase sources of income, mainly through foreign aid and FDI; and 2) to decrease military spending. Both objectives required peace with Israel.

\section{EGYPT AND THE}

\section{COLD WAR}

Like most states, Egypt was greatly influenced by the Cold War, as much development. According to an editorial in the January 2I, I977 edition of the Egyptian Gazette, Egypt's best hope for economic gain was to "opt out of the war with Israel altogether."xii In early November I977, shortly before Sadat's trip to Jerusalem, several major companies, including Ford Motor Company, Coca-Cola, Colgate-Palmolive, Motorola, and Xerox, were willing to open business in Egypt, but because of their dealings with Israel, the Egyptian Boycott Office opposed their entry. xiii Peace with ment and military aid was available from the Soviet Union and the United States (and their respective allies). In the Arab world, the Soviet Union took the dominant role in providing defense and economic aid; Egypt, too, fell under Soviet influence during the I950s and I960s under the leadership of Nasser. When Sadat took power after Nasser's death in 1970 , he began secret talks with the United States to help repair the damage done to American-Egyptian relations by the War of 1967 . 
In I955, the United States refused to provide arms to Nasser's revolutionary regime in Egypt. As a result, Nasser turned to the default arms dealer to the Arab world, the Soviet Union. xiv However, financial aid from the Soviet Union was less forthcoming. The need to fund the national budget, combined with the removal of Western aid, led to the nationalization of the Suez Canal and the subsequent war with Israel in I956. Egypt's leadership in the war with Israel helped propel the country to the front of the pan-Arab movement, making Nasser conform to the movement's ideals. One key tenet of pan-Arabism was economic selfdependence and the maintenance of a favorable balance of trade. As a result, Nasser nationalized a string of privatelyowned foreign and domestic industries in the late I950s and early ig Gos.

Despite these nationalizations, the United States resumed economic aid to Egypt in the early I96os. When in I964 Egypt continued to favor the Soviet Union, as it was the superpower most likely to help foster pan-Arabism, the United States withdrew economic aid again from Egypt.xv Despite Nasser's efforts to make Egypt self-sufficient, the the Soviet Union for arms and on the United States and Arab countries for economic assistance.

Following Nasser's death in I970 and an immediate jockeying for power, his eventual successor, Sadat, pursued a different course. Because the Soviet Union had unsuccessfully interfered in the Egyptian power struggle and attempted to install a leader more sympathetic toward Soviet interests, the Soviets earned Sadat's contempt and distrust.xviii In June I970, the United States issued the Rogers Plan for a peaceful end to the War of Attrition against Israel. In response to Soviet delays in arms shipments and attempts at interference in the transfer of power in Egypt, Sadat signaled to the Americans his readiness to work to bring about regional peace. His willingness to work with the Americans in I970 and I97I, in the opinion of historian Kirk Beattie, betrayed the view held by Sadat that the "United States alone held the key to the conflict's resolution because the United States, in his estimation, was the only true superpower."xix Still, in I971, Sadat signed a Soviet-Egyptian friendship pact, much to the dismay of the Americans.

\section{"Egypt's leadership in the war with Israel helped propel the country to the front of the pan-Arab movement, making Nasser conform to the movement's ideals."}

consequence of the United States' withdrawal of economic aid was drastic: Egypt's gross national product growth fell from 6.4 percent in fiscal year 1963 -I964 to 0.3 percent in fiscal year 1966-I967.xvi Following defeat in the War of I9 67 , rich oil-producing countries in the Middle East tried to compensate for the economic damage inflicted by the closure of the Suez Canal and the destruction of Egyptian oil refineries. The Soviet Union replaced the \$I-I.5 billion in equipment lost during the War of I967.xvii Thus, Nasser's foreign policy was marked by a dependency upon
Most of the discussions with the United States occurred through back channels, including secure telephone lines from Sadat's home to Washington and messages conveyed during secret meetings with members of the United States Interests Office in Cairo. ${ }^{x x}$ In February I97I, Egypt made a significant move towards the United States by complying with the United Nations Jarring Proposal, which was based on United Nations Resolution 242. Egypt complied with the Jarring Proposal's requests, while Israel mainly ignored it. In doing so, Sadat hoped to show the United States that 
he was serious about making peace. In April, when Sadat made a clear and specific peace settlement proposal that President Nixon and the United States State Department did not take seriously, xxi he became angry with the Americans for not rewarding Egypt's willingness to make peace and for not punishing Israel's intransigence.

Henry Kissinger told Sadat that there would have to be a change in the status quo before any peace would be considered on terms acceptable to Sadat.xxii Yet, the expulsion of the Soviet military advisors from Egypt in July I 972 was apparently not enough of a change to please the Americans, as they did not attempt to provide any positive response to the act. Hence, Sadat began preparations for war. Interestingly, the Yom Kippur War of I973 helped bring peace, by restoring the pride the Egyptians lost in I9 67 and humbling the Israelis to the point of being able to consider relinquishing the Sinai. Equally interesting is the United States response to Egypt's aggression-increased foreign investment. In early 1974, the United States offered over \$180 million in loans funded by the government and private businesses for the construction of an oil pipeline from the Suez Canal to the Mediterranean Sea-a project that, while it never actually came to fruition, would have been of great benefit to the Egyptians. xxiii

The United States, to the exclusion of the Soviet Union, was heavily involved in the ceasefire agreements following the Yom Kippur War. The signature of the second Sinai ceasefire agreement in September 1975 "helped drive a stake in Egyptian-Soviet relations."xxiv Six months later, the Egyptians broke their friendship treaty with the Soviets. In response, the Americans increased their aid: US aid was \$371.9 million in 1975 and \$986.6 million in 1976. Xxv By May of I977, following the Food Riots, Arab aid topped \$I.5 billion and US aid topped \$I.O billion.xxvi By the summer of that year, Egypt was no longer sending cotton to the Soviet Union, and the United States was supplying Egypt with military goods. ${ }^{x x v i i}$

At this time, the Soviet Union was also supporting increas- ingly hostile regimes in neighboring Libya, Sudan, and Chad. Sadat blamed Soviet-backed Libyan Communists for instigating the Food Riots earlier in the year and feared that the Soviet Union could persuade Chad and Sudan, both through its own strength and through Libya, to cut off the lifeline of Egypt - the Nile River.xxviii This potential conflict with Libya, Sudan, and Chad may have contributed to Sadat's desire for a quicker peace with Israel, so he could move his army from the Egyptian-Israeli border to the borders with Libya and Sudan.

The Soviet-American joint announcement of a new Geneva Conference surprised Sadat. Indeed, it could have been seen as an insult after Egypt undertook four years of distancing from the Soviet Union. Shortly after the announcement, Sadat began sending out feelers to see if Israel's Prime Minister Menachim Begin would respond positively to his potential trip to Jerusalem, a trip that materialized in November I977. Sadat's speech in front of the Israeli Knesset started two processes: ostracization from the Arab world and negotiations between Israel, the United States, and Egypt, which culminated in the September I978 Camp David Accords. The winding paths of these negotiations have little bearing on Egypt's economic reasons for peace with Israel, yet it should be noted that there was little open discussion during the Camp David negotiations about the economic repercussions to peace, according to memoirs written by President Jimmy Carter and Anwar Al-Sadat. What is important is that the Camp David Accords of 1978 marked the culmination of eight years of attempts by Sadat for peace, and that the desire for peace stemmed in large part from economic motives.

\section{APPLICATIONS IN THEORY}

I will now use the information discussed above and attempt to apply these facts to several concepts in international theory, such as ripeness in peaceful territorial change and negotiating for side benefits. A condition of ripeness, stemming from a mutually harmful stalemate and a mutual interest in the United States as a common ally, existed in the Israeli-Egyptian conflict. Because this paper has fo- 
cused almost exclusively on the Egyptian economy and foreign policy, I will only address ripeness in Egypt. Egypt negotiated with Israel for side benefits mentioned above, such as foreign aid and increased FDI.

From I970 to 1973, the stalemate between Egypt and Israel was especially damaging to Egypt, as the country had to maintain expensive forces on the Sinai border and could not cut its ties with the Soviets, which cost Egypt the United States' favor. An end to the stalemate may have been in Egypt's economic interest, but at the time, the United States would not mediate a deal acceptable to Sadat. The I 973 Yom Kippur War, which dealt a blow to the Israeli ego, ended this stalemate. By working closely with the United. States to develop the two Sinai ceasefire agreements, Egypt received more favor (and favors) from the United States. By I978, the United States, under President Jimmy Carter, was willing to broker a deal more acceptable to Sadat. In addi- tion, both the Israelis and Egyptians were willing to trade land for peace. This stalemate ended in a peace agreement. The contents of the peace agreement and, from the accounts of Sadat and Carter in their respective memoirs, the negotiations at Camp David focused little on the direct economic effects of peace. There were some side agreements whereby the Egyptian air force received American aid and the Israelis purchased oil at market value from the Sinai oil wells which were turned over to Egyptian control. However, the bulk of the negotiations seemed to focus on other issues - the future of the Palestinians and Israeli settlements in the Sinai, for example. ${ }^{\text {xxix }}$

Although the Camp David Accords netted little in terms of formal arrangements with the United States, Sadat had every reason to think that the United States would provide some reward for his willingness to sign a United Statesmediated peace deal. After signing the United States-

ANWAR AL-SADAT, IIMMY CARTER, AND MENACHEM BEGIN SHAKING HANDS AT CAMP DAVID ACCORD SIGNING

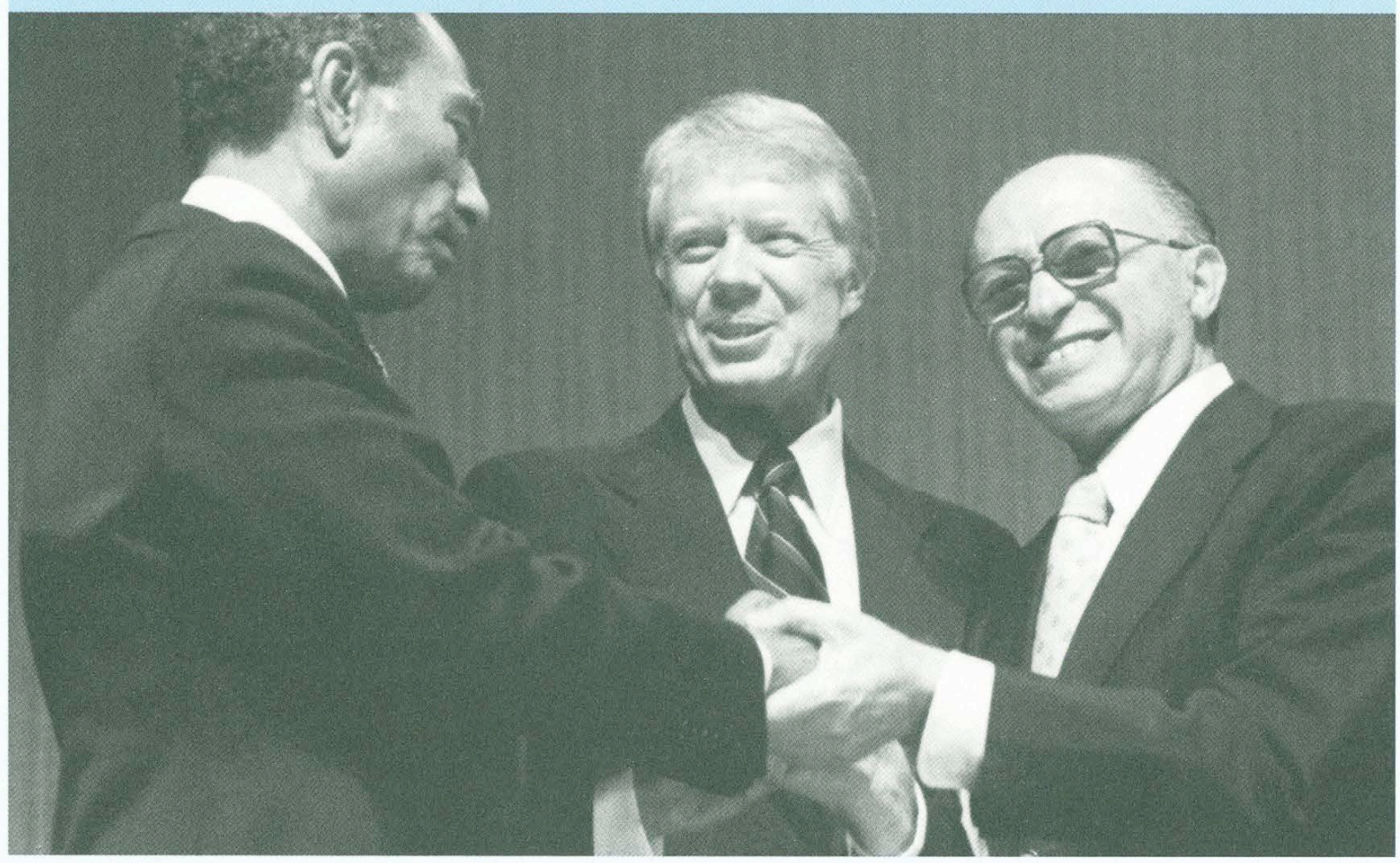


mediated Sinai ceasefire agreements, Egypt received increased development aid from the United States. By I977, the United States was providing arms to only three countries in the Middle East: Israel, Saudi Arabia, and Egypt. Sadat saw the benefits of going along with United States initiatives, and in 1978 decided to launch an initiative of his own that would endear him even more to the hearts of United States' policymakers with the unspoken hope that it would lead to more American foreign aid.

\section{CONCLUSION}

The economic motivation for Camp David was not there. After all, the Arabs offered him an option. He knew the Arab world would boycott Egypt; he didn't have any offer from the U.S. side or others at the time, so it was a genuine effort by him to make peace.

-Mustafas Khalil, Prime Minister of Egypt 1978-1980.xxx

Is Prime Minister Mustafas Khalil correct? It would be a fool's errand to try to prove in this paper that a true desire for peace for peace's sake did not motivate Sadat, at least in part, to seek peace with Israel. The psychological aspects of this peace process are, indeed, an important topic. However, Egypt's foreign policy history shows that Sadat understood the correlation between peace and Western aid, and economic history shows that Sadat's policies required Western aid and investment in order to succeed. Whether or not Egypt's economy improved following the Camp David Accords is irrelevant to this study; Sadat's intentions are the focus.

Because it is human nature to aggrandize one's own benevolence for posterity, sources such as the memoirs of Sadat and President Carter are not wholly useful, as they, by nature, tend to accentuate the moralistic aspects of their policy decisions. This is why secondary historical sources have primarily been relied upon for this paper. Hence, former Prime Minister Khalil's statement should be scrutinized through the lens of history.
Indeed, the Arabs did offer increased aid to Egypt in an effort to steer Sadat away from the negotiating table. In a November 1978 meeting of the Arab League in Baghdad, Lebanon alone offered Sadat \$5 billion over ten years if he would not attend the scheduled Camp David summit. Sadat's ironic reply was that his nation's future was not for sale. ${ }^{\text {xxxi }}$ In fact, the future of Sadat's nation was for sale, but not for a mere \$500 million in aid per year. Instead, its price was the expectation of increased Western aid and FDI.

While Khalil is correct in saying that there was never an explicit agreement that the United States would increase their aid to Egypt following a peace with Israel, a look at the his-

\section{"Egypt's peace movements towards Israel in the 1970 S can be cynically but accurately viewed as an extension of Sadat's domestic economic policies."}

tory of Egyptian-American relations makes it appear reasonable for Sadat to assume that peace with Israel would lead to increased American foreign aid. Throughout the I970s, as Egypt drew closer to the United States, their aid packages increased. The increase which followed the signing of the two Sinai ceasefire agreements was especially dramatic: US aid was \$37I.9 million in I975 and \$986.6 million in 1976 , the year after the signature of the second Sinai agreement.xxxii A similar jump in United States aid took place after the signing of the Camp David Accords: from \$1.0 billion in I977 to \$2.2 billion in I979. Xxxiii Not only did peace with Israel promise increases in foreign aid, but it also allowed companies such as Coca-Cola to enter 
the country despite their dealings with Israel, something that kept them out of Egypt before the Camp David Accords. FDI increased from to percent of all Egyptian investment in 1977 to I4 percent in I979.

In summation-, Egypt's peace movements towards Israel in the I970s can be cynically but accurately viewed as an extension of Sadat's domestic economic policies. At the very least, one must incorporate this view into any complete understanding of the I970s peace between Egypt and Israel. Sadat's infitah program of liberalization of the economy could only succeed if foreign development aid and FDI levels were high. As Egypt moved from the Soviet Union towards the United States, its foreign aid and foreign investment increased, and Sadat exploited this pattern and throughout the I970s. Domestically, cutting subsidies was obviously not an option following the January I978 riots, yet balancing the budget was a necessity; cutting military spending was a clear way to achieve this goal. Sadat's attempts to fix these domestic economic issues resulted in his decision to seek a lasting peace with Israel.

\section{ENDNOTES}

i. Friedlander (6)

ii. Friedlander (208)

iii. McDermott (I22)

iv. McDermott (I22)

v. Beattie (3)

vi. Beattie (93)

vii. McDermott (I3I)

viii. Friedlander (6)

ix. Friedlander (4)

x. Beattie (2I4)

ix. Friedlander (5)

x. Beattie (I39)

xi. Beattie (I4I)

xii. Quoted in Beattie (220)

xiii. Beattie (220)

xiv. Beattie (5)

xv. Beattie (5)

xvi. Beattie (6)

xvii. McDermott (127)

xviii. Israeli (32)

xix. Beattie (50)

xx. Beattie (55)

xxi. Beattie (87)

xxii. Beattie (I32) xxiii. Beattie (I38)

xxiv. Beattie (I79)

xxv. Beattie (I79)

xxvi. Beattie (2IG

xxvii. Friedlander $(67)$

xxviii. Israeli (I53)

xxix. Carter (3-9-403)

xxx. Quoted in Beattie (228)

xxxi. Friedlander (257)

xxxii. Beattie (179)

xxxiii. Beattie (23I)

\section{REFERENCES}

Beattie, K. J. 2000. Egypt during the Sadat Years. New York: Palgrave.

Carter, J. I982. Keeping Faith: Memoirs of a President. Toronto: Batnam Books.

Friedlander, M. 1983. Sadat and Begin: The domestic politics of peacemaking. Boulder, Col.: Westview Press.

Israeli, R. I. I981. Egypt-Aspects of President Anwar Al-Sadat's Political Thought. Jerusalem: The Magness Press.

McDermott, A. 1988. Egypt from Nasser to Mubarak: a flawed revolution. London: Croom Hill. 